Savytska Nataliia, Doctor of Sciences (Economics), Prof. ORCID 0000-0001-6569-6772; ResearcherID: I-7458-2018

Ukraine

Afanasieva Oksana, $\mathrm{PhD}$ in Economics, Associate Prof. Kharkiv State University of Food Technology and Trade, Kharkiv

ORCID: 0000-0002-5269-4281; ResearcherID: N-1861-2018

\title{
MARKETING TOOLS FOR PROMOTING INNOVATIVE FOOD PRODUCT FOR YOUTH
}

The urgency of the problem of inappropriate nutrition of young people is caused by significant deviations from the norms of consumption of nutrients, acceleration of the rhythm of life, lack of awareness of the audience about fast and nutritious food. Therefore, there is a need for marketing research and substantiation of tools for bringing to the market the food products with proven biological effects for youth. The paper presents the results of research using the questionnaire survey method to determine consumers' preferences and tastes, as well as potential demand for new products. The AID method defines the target segments of potential consumers: "teens», "students», «young specialists» and «young people in shoulder straps». For each of them an innovative product is offered. The consumer characteristics of the developed line of snack products and its advantages are substantiated. Recommendations on the formation of a culture of consumption and promotion of the latest products for youth were developed. For each consumer segment, a separate marketing concept was developed for the launch of a new product on the market. The concept allows to clearly position the product in the minds of consumers, to formulate standards of consumption of these products through proactive marketing tools and marketing interaction in the proposed system of the marketing mix $« 5 P+C »$. The paper has a research character. Its scientific and practical value lies in the systematic approach to the introduction of new food products into the market and the systematization of food-marketing tools.

Keywords Relevance of research topic: marketing research, marketing of innovations, food-marketing. 
Савицька Наталія, Афанасьсва Оксана. Маркетингові інструменти просування інноваційних ХАРЧОВИХ продуктів для молоді.

Анотація: Розглянуто вирішення проблеми неправильного харчування молоді шляхом формування культури здорового харчування інструментами проактивного маркетингу та маркетингу взаємодії. Наведено результати дослідження з використанням методу анкетування для визначення переваг $i$ смаків споживачів, а також потенційного попиту на нові продукти. Методом AID визначено иільові сегменти потенційних споживачів: «підлітки», «студенти», «молоді фахівці» $i$ «молоді люди в погонах». Обгрунтовано споживчі характеристики розробленої лінійки інноваційних снекових продуктів $i$ їх переваги. Розроблено рекомендащії щодо формування культури споживання та просування нових харчових продуктів для молоді. Для кожного споживчого сегменту розроблена окрема маркетингова конщепџія для запуску нового продукту на ринку. Конщепція дозволяє чітко позиціонувати продукт у свідомості споживачів методами запропонованої системи комплексу маркетингу «5P $+C »$. Стаття має дослідницький характер. Наукова і практична изінність одержаних результатів полягає в системному підході до просування на ринок інновачійних харчових продуктів.

Ключові слова: маркетингові дослідження, маркетинг інновачій, продовольчий маркетинг.

Formulation of the problem. The urgency of the problem of rational nutrition of young people and students is due to the following main factors: significant deviations from norms associated with insufficiency or excess of nutrients. This causes a violation of metabolic processes and leads to the development of a number of alimentary diseases; high rhythm of life and lack of time for healthy eating; lack of awareness of fast and healthy nutrition as a basis for a healthy lifestyle.

The health problems of the nation have a multifaceted complex nature, the solution of which is a global socio-economic challenge to the goals of sustainable development proclaimed by the United Nations in 2018 as a food security and nutrition challenge; conscious consumption and production; providing health and wellbeing [10]. According to the results of the NielsenHealthyrevolution study, the trend of healthy eating is increasing in Ukraine [8], but this is not typical for young people's eating behavior.

The main types of healthy food products: least content or full missing of fats, organic products, sugarless products and functional food products.

Consequently, in modern conditions, innovative processes are being activated in relation to the development of food products with proven biological effects for youth. In order to saturate the food market with such products, it is necessary to expand their industrial production and provide proper marketing support for their promotion to the market through the tools of food-marketing. 
Analysis of recent researches and publications. Marketing problems of the formation of demand for functional food products and their market entry are considered in the scientific articles of O. Zhegus, V. Yevlash, S. Nikitin [11], M. Mardar [7], analysis of motivational and personal factors of customer behavior of I. Anninou, GR. Foxall [1], demonstrative consumption of functional health products J. Gineikiene, J. Kiudyte, M. Degutis [5], eating healthy to impress - D. Barauskaite, J. Gineikiene, BM. Fennis, V. Auruskeviciene, M. Yamaguchi, N. Kondo [2] and others.

The conducted analysis of recent research suggests that most sources focus on the general aspects of the production of functional foods and marketing research in the food market, while integrated solutions for the production, withdrawal and promotion of food products with proven biological effects for young people remain neglected which determines the need for additional research on target market segments and the development of marketing measures for each of them. The urgency of the abovementioned aspects, their inadequate theoretical substantiation and practical application led to the choice of this area of research.

Presenting main material. The object of research is the process of introduction and promotion of new food products with proven biological effects on the market. The subject of the study is the toolkit for forming a marketing mix for innovative food products for young people.

The main results were obtained using general scientific and special methods of marketing research: analysis, systematization and generalization; economic-statistical, comparative and situational analysis; strategic analysis, content analysis, benchmarking, AID method, graphical, observation and questionnaire. For substantiation of technological solutions for the production of proven biological products for the prophylaxis of iodine and iron deficiency, lipid metabolism, carbohydrate, uric acid, as well as the mobilization of internal reserves of the organism, increased work capacity and resistance to loading, strengthening of immunity, methods of preclinical research in laboratory animals were used; the method of clinical testing of a trial lot of products.

The results obtained are of a complex nature, since they included the following steps: 1) Marketing research of potential demand for innovative products. 2) Development of technology for the production of innovative products. 3) Pre-clinical studies of new products on animals. 4) Issue of a trial lot of innovative products by the company «Sweet World» and its clinical testing on one of the target segments of consumers. 5) Development of recommendations for the concept of an innovative product for each target audience and marketing complex on the implementation of these concepts on the market.

At the first stage, to validate the market introduction of innovative products, a marketing research was conducted using a questionnaire survey method to determine the health problems among young people, as well as consumer preferences and tastes. The sample population of this study was 657 people. The sampling was carried out with the help of non-repeat quota selection. The number of respondents (657 persons) 
is a representative one, since for a city with a population of one million inhabitants there are enough 400 respondents, and in the city of Kharkiv at the time of the survey by statistical data, on February 1, 2018, 1449414 people lived [3]. The sampling error was $\pm 5 \%$, which is a sufficient level of reliability for field marketing research [9].

For marketing research of potential consumers an electronic questionnaire was used in the Facebook social network. The questionnaire was created using the GoogleForms application, which allowed us to conduct an online survey.

A questionnaire survey showed that $61 \%$ of the respondents had symptoms similar to iodine and iron deficiency conditions. Such condition correlates with World Health Organization statistics: 9 out of 10 children and 6 out of 10 adults have iodine deficiency, and one-third of all humans have iron deficiency pathologies [10]. Therefore, the essence of the technological idea is to create a new product for youth dry breakfast - bars with proven biological effects, with a balanced composition containing natural supplements for the prevention of alimentary states. Further on the results of the survey it is determined that:

- the majority of consumers of snack products (namely $72.3 \%$ of respondents) are young people aged 14-35 years, therefore, when placing innovative products on the market should focus on the needs of this age group of consumers;

- among the types of snack products, according to the advantages, the first place is occupied by bars (57.3\% of respondents), therefore it is most expedient to produce products of this group in the form of bars;

- the differentiation of needs and expectations regarding the bars among young people of all ages and occupations was identified; therefore, measures aimed at promoting innovative products to different target consumers of consumers should be clearly identified;

- one should pay attention to the factors that motivate young people to buy new products, the most important being noted: the affordable price $(43.2 \%)$, the natural composition and utility of the product $(27.1 \%)$ and positive reviews in social networks (26.4\%);

Investigating the potential demand for a new bar, it was found that most consumers $45.1 \%$ agree to buy it, after studying the information about the composition of this product. Consequently, the task of the company-manufacturer should focus on informing consumers about the benefits of new bars (fig. 1).

Based on our marketing research, target audiences of potential consumers were identified: teens (middle and high school students), students, young specialists and youth with shoulder straps (fig. 1):

1) «Teenagers» - these are children of middle and senior school age (14-17 years old) who have pocket money from their parents for their own small purchases of food. They decide on the purchase of fast snacks, sweets, etc. on their own. 


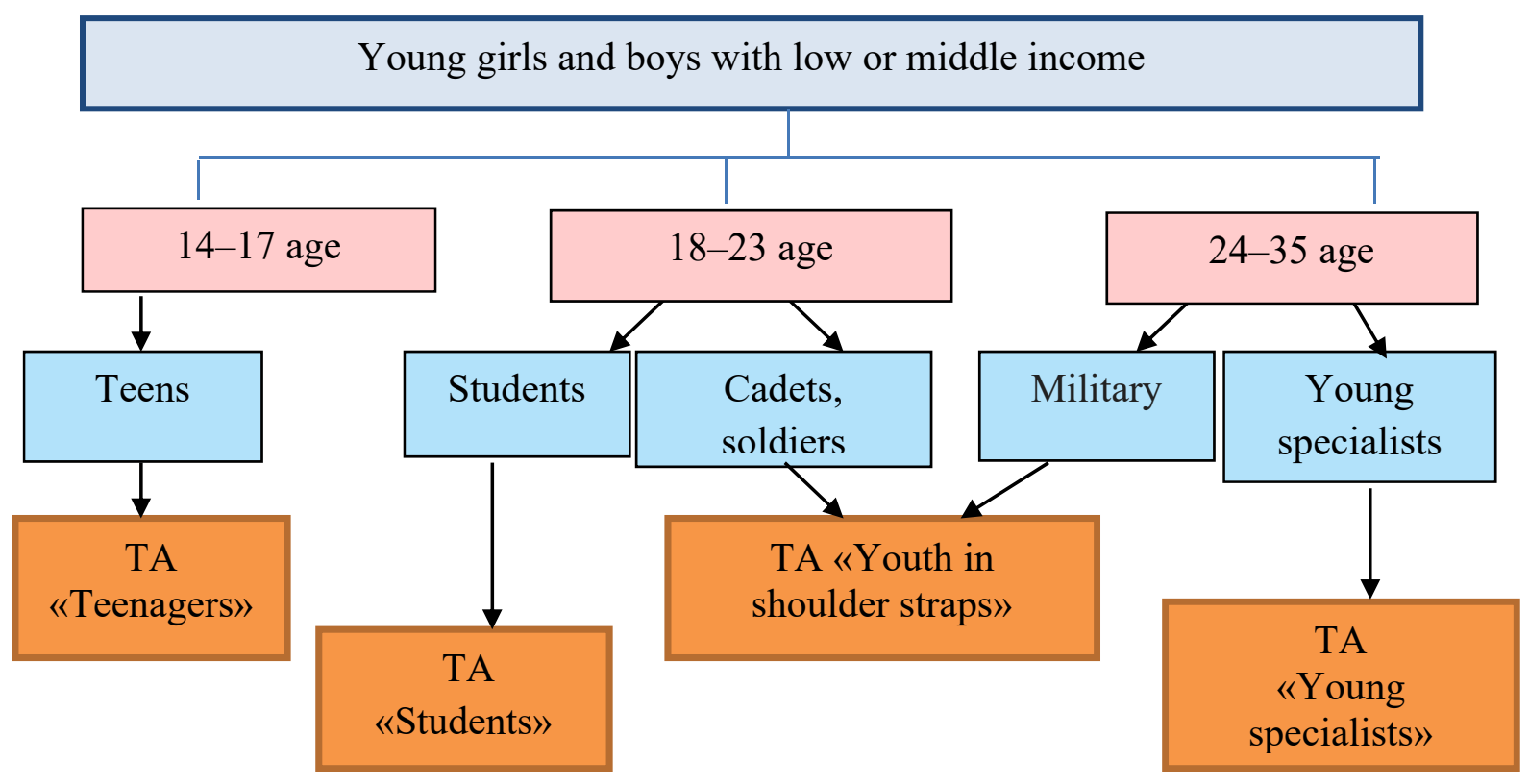

Fig. 1. Market segmentation by AID method

2) «Students» - are young people aged 18 to 25 who study, hence needing a fast-food lunch at affordable prices.

3) «Youth in shoulder straps» - these are cadets and servicemen aged 18-35 who have an active lifestyle, have both mental and significant physical activity, sometimes in stressful situations, and therefore need snacks to restore strength, resistance to stress, are guided by the choice of not only inexpensive products, but also high-income for maintenance of work capacity.

4) «Young specialists» - are young people aged 24-35, working, family or single, need to restore strength for active activities, while choosing more nutritious and healthy snacks.

Due to the specific needs of each of the consumer segments for the formation of demand for new products, it is necessary to use a strategy of differentiated marketing, that is, to adapt marketing decisions to the features of the separated segments and to develop separate marketing programs for them.

On the basis of marketing research the technologies of production of a line of innovative products for the selected consumer segments were developed. For target audiences: «Teenagers»and «Students» are offered «Protein bar with heme iron»; «Youth with shoulder straps» - energy-saving bar «The Winner»; «Young specialists» - a bar with iodine and selenium. Composition of the newest special-purpose products is multicomponent, in which the ratio of ingredients forms a complex of biologically active substances of natural origin.

The finished product is shaped like a bar, has a homogeneous mass, brown color, an elastic consistency, with a glossy surface and a fruity taste. The developed product is supposed to produce a mass of $30 \mathrm{~g}$ or $60 \mathrm{~g}$ in black or milk chocolate. The 
advantages of its production technology are the minimum heat treatment, which allows to save all nutrients, convenient packaging, extended shelf life without adding artificial preservatives and low energy consumption for its production. Bars contain antioxidants, iodine and iron in an easily accessible organic form for an organism. They have attractive appearance, pleasant taste, comfortable packaging and are externally they are usual sweets. But unlike most bars, they do not contain sugar and palm oil. The ability to quickly restore energy loss causes the attractiveness of bars for nutrition to a wide audience of young people, including cadets, young soldiers and the ability to include bars in rations and dry rations packs of the Armed Forces. These facts strongly confirm the high social utility of the newest products of bars: «Protein with heme iron», energy bar - «The winner» and «Bar with iodine and selenium».

At the third stage, the biological effect of the bars is proved by preclinical studies in laboratory animals. At the fourth stage, the «Winner» bars were included in the daily diet of servicemen of the Armed Forces of Ukraine, namely the servicemen of the National Academy of the National Guard of Ukraine (Kharkiv), who were in different conditions of service activity - were at the point of permanent disposition and received moderate physical activity and performed military and combat tasks in the field, received large physical and psycho-emotional loads. The conducted clinical studies of blood parameters (hemoglobin level and the number of red blood cells) of all participants before and after the use of bars showed a significant increase in hemoglobin content and the number of red blood cells. In addition, surveys showed improvements in the psycho-emotional condition. Based on the conducted research, the worked out and recommended schedule of reception of the latest products of bars by military personnel was prepared.

At the fifth stage, recommendations were made to create a culture of consumption and promote the proposed bars in the market for dry breakfasts for young people. For each consumer segment, a separate concept was developed, which will allow the product to be clearly positioned in the minds of consumers. The $5 \mathrm{P}+\mathrm{C}$ mix marketing complex is proposed for the formation of standards for the consumption of advanced products by proactive marketing and interaction marketing tools.

To form the standards for conscious consumption of new products, recommendations have been made to use the tools of the proactive $« 5 \mathrm{P}+\mathrm{C} »$ (Product + Price + Place + Promotion + Rarticipants + Culture $=$ Marketing-Mix $)$ marketing for each product for a specific target audience. The emphasis is on low-budget measures, which will not significantly affect the price increase of products . «Protein bar with hem iron», the price is 8-10 UAH for the «Teens» and «Students» segments, distribution channels: school dining, sports and dance sections, supermarket departments, kiosks near the school and sports grounds. Promotion through SMM: Instagram Entertainment Group for Students in Social Networks, advertisements through bloggers, opinion leaders, through YouTube gaming channels at sales sites. Content: games, storytelling, entertainment posts. Event-marketing: sporting and 
educational events for senior students with gifts and tastings, Student's Day, St. Valentine's Day, Sports holidays of the city level (marathons, football matches, etc.) participation with gifts.

Table 1

\section{Marketing mix for an innovative product}

\begin{tabular}{|c|c|c|c|c|}
\hline \multirow{2}{*}{$\begin{array}{l}\text { Marketing } \\
\quad \text { Mix }\end{array}$} & \multicolumn{4}{|c|}{ Conceptions of innovative product } \\
\hline & $\begin{array}{l}\text { «Smart } \\
\text { Junior» }\end{array}$ & $\begin{array}{l}\text { «Smart } \\
\text { Student» }\end{array}$ & «Smart Winner» & $\begin{array}{l}\text { «Smart } \\
\text { Energy» }\end{array}$ \\
\hline Product & \multicolumn{2}{|c|}{ Protein bar with heme iron, $60 \mathrm{~g}$} & $\begin{array}{l}\text { Energy-saving bar } \\
\text { «Winner», } 60 \mathrm{~g} .\end{array}$ & $\begin{array}{l}\text { Bar with iodine and } \\
\text { selene } \\
60 \mathrm{~g} .\end{array}$ \\
\hline Price & \multicolumn{2}{|c|}{$8-10 z$} & $10-15 q$ & $8-10 \not$ \\
\hline Place & $\begin{array}{l}\text { School canteens, } \\
\text { sports and dance } \\
\text { classes, departments } \\
\text { at supermarkets, } \\
\text { kiosks near schools } \\
\text { and sportgrounds }\end{array}$ & $\begin{array}{c}\text { Cafes and buffets in } \\
\text { educational } \\
\text { institutions, sport } \\
\text { classes, } \\
\text { online stores }\end{array}$ & $\begin{array}{l}\text { Cafes and buffets } \\
\text { in military } \\
\text { educational } \\
\text { institutions or } \\
\text { military units and } \\
\text { kiosks near them. } \\
\text { Combat rations for } \\
\text { field trips and } \\
\text { business trips }\end{array}$ & $\begin{array}{c}\text { Departments at } \\
\text { supermarkets, } \\
\text { online stores, direct } \\
\text { sales, cafes and } \\
\text { canteens in office } \\
\text { centers }\end{array}$ \\
\hline Promotion & $\begin{array}{l}\text { SMM: } \\
\text { entertainment groups } \\
\text { for schoolchildren in } \\
\text { the social networks } \\
\text { as VK, Instagram, } \\
\text { bloggers`ads, ads at } \\
\text { YouTube video game } \\
\text { channels, st the } \\
\text { points of Content } \\
\text { sales: games, story } \\
\text { telling, entertainment } \\
\text { posts } \\
\text { Event marketing: } \\
\text { sports and } \\
\text { educational events } \\
\text { for senior school with } \\
\text { gifts and tastings }\end{array}$ & $\begin{array}{c}\text { SMM: } \\
\text { entertainment and } \\
\text { education groups in } \\
\text { social networks as } \\
\text { Facebook, VK, } \\
\text { Instagram, } \\
\text { educational video } \\
\text { channels at } \\
\text { YouTube, } \\
\text { promotions, gifts, } \\
\text { tastings } \\
\text { Event marketing: } \\
\text { Student's Day, St. } \\
\text { Valentine's Day, } \\
\text { city-level sports } \\
\text { events (marathons, } \\
\text { football matches, } \\
\text { etc.) - participation } \\
\text { with gifts }\end{array}$ & $\begin{array}{c}\text { SMM: } \\
\text { groups for cadets } \\
\text { and military in the } \\
\text { social networks as } \\
\text { Facebook VK, } \\
\text { Instagram, ads at } \\
\text { Youtube military } \\
\text { channels } \\
\text { Event marketing: } \\
\text { Defender's Day, } \\
\text { military holidays } \\
\text { (National Guard } \\
\text { Day, etc.) - } \\
\text { participation in } \\
\text { military } \\
\text { educational } \\
\text { institutions during } \\
\text { holidays }\end{array}$ & $\begin{array}{c}\text { SMM: } \\
\text { groups at social } \\
\text { networks as } \\
\text { Facebook, VK, } \\
\text { Instagram, } \\
\text { YouTube, Twitter, } \\
\text { LinkedIn, bloggers } \\
\text { ads (LiveJournal, } \\
\text { LiveInternet, } \\
\text { authors blogs), } \\
\text { promotions, gifts, } \\
\text { tastings } \\
\text { Event marketing: } \\
\text { Presentations at } \\
\text { youth eateries and } \\
\text { during city holidays } \\
\text { (City day, sports } \\
\text { holiday, marathons, } \\
\text { etc.) }\end{array}$ \\
\hline Participants & \multicolumn{4}{|c|}{$\begin{array}{l}\text { System`s development of internal and external marketing: trainings and motivation of the } \\
\text { staff, suppliers, intermediaries and contact audiences }\end{array}$} \\
\hline Culture & \multicolumn{4}{|c|}{$\begin{array}{l}\text { Measures of propaganda and learning of conscious consumption, involvement of opinion } \\
\text { leaders for product reviews in the Internet and media in case to form the standards and the } \\
\text { culture consumption of a new product. }\end{array}$} \\
\hline
\end{tabular}


Energy-saving bar «Winner», the price is $10-15$ UAH for young soldiers. Sale through cafes and buffets in military educational institutions or military units, kiosks near them, dry rations packs for field trips and business trips. Promotion through SMM: Groups for cadets and military in social networks Facebook, Instagram, advertising on YouTube on military topics. Event-marketing: Day of the defender of the fatherland, military holidays (National Guard Day, etc.) - participation in holidays in military educational institutions.

«Bar with iodine and selenium», the price is also 10-15 UAH for the segment «Young specialists». Realized in supermarkets, online stores, direct sales, cafes and dining rooms at office centers. Promotion through SMM: Facebook social networking groups, Instagram, YouTube video channels, Twitter, LinkedIn, bloggers (LiveJournal, LiveInternet, author's blogs), promotions, gifts, tastings. Event-marketing: Presentations at youth food establishments, city holidays (City day, sports holiday, marathons, etc.).

For the whole line of products, the marketing tools of Participants and Culture are to form the interaction of all participants in the process of production, marketing and promotion, and to create a culture of conscious consumption of the custom product, taking into account the specific behavior of consumers of each target audience.

For the segment «Teenagers» we offer the concept of «Smart Junior», the consumption of the bar allows you to solve the problem of choosing an inexpensive tasty and healthy snack. The image is active and funny teens, the communication idea «You can do more!».

For the «Students» segment, the concept of «Smart Student», the problem of fast snacks for improving the mental activity. The image is a smart student, a communication idea - «Smart choice for smart decisions!»

For the «Young Specialists» segment, we offer the concept «SmartEnergy», a selection of products for a healthy snack that increases energy and immunity. The image is successful and energetic young people, the communicative idea - «Warm up with smart energy!»

For the «Youth with shoulder straps» segment, the concept of «Smart Winner» is the selection of useful and nutritious products for a fast snack. The image is a joyous serviceman, communicative idea - «Smart Food - Quick Victory!»

Conclusion. The emergence of the newest bars in the market for dry breakfasts for young people will enable them to enrich their diets with nutrients, improve their health and improve the cognitive activity of young people. Such products will promote the expansion of the range of useful and inexpensive dry breakfasts, reducing the youth's spending time on cooking and eating, reducing the cost of finished products through the use of domestic raw materials, reducing the number and duration of some technological operations. 


\section{REFERENCES}

1. Anninou I., Foxall GR. (2017), Consumer decision-making for functional foods: insights from a qualitative study, J. of Consumer Marketing, 34(7), P. 552-565.

2. Barauskaite D., Gineikiene J., Fennis BM., Auruskeviciene V., Yamaguchi M., Kondo N. (2018), Eating healthy to impress: How conspicuous consumption, perceived self-control motivation, and descriptive normative influence determine functional food choices, J. Appetite, 131, P. 59-67.

3. DemografIchni dani po Harkivskiy oblasti u sichni 2018 roku: Statistichniy byuleten. [Demographics of Kharkiv region, January 2018: Statistical bulletin] Retrieved from http://kh.ukrstat.gov.ua/ [in Ukrainian]

4. Food safety. Retrieved from https://www.who.int/en/news-room/fact-sheets/ detail/food-safety

5. Gineikiene J., Kiudyte J., Degutis M. (2017), Functional, organic or conventional? Food choices of health conscious and skeptical consumers, Baltic J. of management, 12(2), P. 139-152.

6. Grunert K.G. (2008), European consumers' acceptance of functional foods, Conference on Foods for Health in the 21st Century - A Road Map for the Future, Blackwell Publishing, England,1190, P. 166-173.

7. Mardar M. R. (2015) Formuvannia spozhyvchykh perevah do funktsionalnykh produktiv kharchuvannia na osnovi marketynhovykh doslidzhen [Forming consumer preferences for functional foods based on market research]. Ekonomika kharchovoi promyslovosti. Vol. 1. P. 19-25 [in Ukrainian]

8. Nielsen: v Ukraine rastet trend zdorovogo pitaniya [Nielsen: healthy food trend is growing in Ukraine]. Retrieved from http://mmr.ua/show/nielsen_v_ukraine_ rastet_trend_zdorovogo_pitaniya [in Russian]

9. Paniotto V., Maksymenko V., Kharchenko N. (2004), Statystychnyi analiz sotsiolohichnykh danykh [Statistical analysis of sociological data], VD «KM Akademiia», Kyiv, 591 p.

10. The Sustainable Development Goals Report. Retrieved from https://unstats. un.org/sdgs/report/2019/The-Sustainable-Development-Goals-Report-2019.pdf

11. Zhehus O.V., Yevlash V.V. Nikitin S.V. (2016). Marketynhovi instrumenty prosuvannia funktsionalnykh produktiv kharchuvannia [Functional food promotion marketing tools]. Povnotsinne kharchuvannia: innovatsiini aspekty tekhnolohii, enerhoefektyvnoho vyrobnytstva, zberihannia ta marketynhu. P. 516-545 [in Ukrainian] 